\title{
Literature Review on the Factors Influencing the Usage of Social Media among Entrepreneurs in Malaysia
}

\author{
Noor Aziah Abu Bakar, Ahmad Fauzi Ahmad Zaini \\ Kolej Universiti Poly-Tech MARA, Kuala Lumpur, Malaysia \\ Email: aziah1209@gmail.com
}

How to cite this paper: Abu Bakar, N. A. \& Ahmad Zaini, A. F. (2022). Literature Review on the Factors Influencing the Usage of Social Media among Entrepreneurs in Malaysia. Open Journal of Social Sciences, 10, 409-419.

https://doi.org/10.4236/jss.2022.101031

Received: December 21, 2021

Accepted: January 24, 2022

Published: January 27, 2022

Copyright $\odot 2022$ by author(s) and Scientific Research Publishing Inc. This work is licensed under the Creative Commons Attribution International License (CC BY 4.0).

http://creativecommons.org/licenses/by/4.0/

(c) (i) Open Access

\begin{abstract}
The conceptual study is to demonstrate the progress of the discussions between performance expectancy, social influence, facilitating condition, propensity to sharing information, viral marketing expectancy and fear of pandemic as influencing factors toward social media usage among entrepreneurs. Social media usage becomes the focus of researchers and organization, because of the effectiveness and efficiency of social media as a marketing tool in the business environment. Logically, variables (performance expectancy, social influence, facilitating condition, propensity to sharing information, viral marketing expectancy and fear of pandemic) may influence social media usage as a marketing tool to help entrepreneurs gain competitive edges, build relationship with customers and build business presence in the market. However, previous studies on the relationship between performance expectancy, social influence, facilitating condition, propensity to sharing information, viral marketing expectancy and fear of pandemic and social media usage as a marketing tool are very limited. This preliminary study aims to answer what factors may influence the entrepreneur's social media usage and find the most significant factors that can contribute towards the usage of social media as marketing tool in Malaysia.
\end{abstract}

\section{Keywords}

Performance Expectancy, Social Influence, Facilitating Condition, Propensity to Sharing Information, Viral Marketing Expectancy, Fear of Pandemic, Social Media Usage

\section{Introduction}

Social media usage as a marketing tool has allowed entrepreneurs immediate in- 
teraction and customer feedback (Camilleri, 2019; Durgam, 2015; Eid, Abdelmoety, \& Agag, 2019; Lin, Li, Yan, \& Turel, 2018). Social media usage is crucial and receives a lot of attention because it involves an economic cost to the entrepreneur and its business by Armesh et al. (2010), Nadaraja \& Yazdanifard (2013), and Vedenhaupt (2016). Generally, the factors that influence actual usage are influenced by performance expectancy, effort expectancy, social influence and facilitating condition (Venkatesh et al., 2003). Moreover, other factors such as attitude and belief (propensity to sharing information, viral marketing expectancy and fear of pandemic) can also influence entrepreneur actual adoption of system usage.

As the pandemic occurs, entrepreneurs suffer problems such as layoffs of employees, financial crunch, employees' health issues, fall in sales and turnover, and customer demands (Kumar \& Ayedee, 2021). However, with potential customers' availability on the internet, it is expected that this is the time for entrepreneurs to take serious action in using social media as their marketing tool. Even Effendi, Sugandini, and Istanto (2020) study found that SMEs affected by the pandemic crisis have a great perception of social media usage and have a high intention to embrace social media as a method to promote their products and link with their customers. In other words, the spreading of pandemic has become a pushing factor for entrepreneurs to embrace e-commerce and social media usage for their business survival (Cheng, 2020).

The definition of social media is networking of like-minded individuals who form a community to be able to communicate with each other on the internet by sharing information and comments between each other. The social media backdrop is a procedure that requires numerous functions consisting of Facebook, Instagram, Twitter, WhatsApp, YouTube, to name a few. The preliminary study aims to develop a theoretical framework for understanding the relationship between performance expectancy, social influence, facilitating condition, propensity to sharing information, viral marketing expectancy and fear of pandemic toward the social media usage as a marketing tool. It is expected that this study could provide more understanding on elements that could influence entrepreneurs to make use of social media as their marketing tool.

\section{Literature Review}

The Internet is a driver for e-commerce in the world nowadays. Surely, one of the most major changes in this decade is the revolution in communication technology and its effect on the way users now relate with companies and with each other (Elawadi, 2016); (Hassan, Shiratuddin, \& Abdul Salam, 2015). There are several advantages to using social media as a marketing tool for entrepreneurs. Edosomwan et al. (2011) suggest that Facebook and Twitter grow to be fully assimilated into our life, becoming an indispensable part of our lifestyles and a norm of activities to do. Fortin and Uncles (2011) postulate that the pace and ease at which information now spreads and goes viral has resulted in better consumer empowerment. 
According to the (Malaysian Communication and Multimedia Commission, 2018), internet users continue to rise to 28.7 million users. Overall, users spent 6.6 hours online in a day. Visiting social networking platforms such as WhatsApp and Facebook are the most popular activities among Internet users. The main explanation with regards to these changes in users' behaviour is the volume of content shared among online consumers.

Despite the importance of social media and the promising capability of social media as a marketing tool, scant research has been conducted on this topic. Existing social media research for a business purpose has primarily been conducted at the big firm rather than focusing on the adoption of social media for entrepreneurs especially in small and medium enterprises (SMEs). The current level, patterns, and factors influencing the adoption of social media as a marketing tool are still unknown, especially from Malaysia's perspective.

\subsection{Social Media Usage}

The issues of entrepreneurs' social media usage have been discussed among scholars, and it is still developing (Camilleri, 2019; Cheng, Liu, \& Li, 2020; Liu \& Bakici, 2019; Serben, 2014; Turan \& Kara, 2018). Scholars have suggested performance expectancy, effort expectancy, social influence and facilitating conditions could influence social media usage (Serben, 2014; Teresa \& Ceyrat 2017; Thomas, Singh, \& Aulia 2017). Besides, such study in Malaysia is still in its infancy, and empirical studies on these issues are highly scarce in Malaysia (Dai et al., 2020; Hassan, Shiratuddin, \& Abdul Salam, 2015; Turner \& Akinremi, 2020).

\subsection{Performance Expectancy}

Performance expectancy refers to "the degree to which an individual perceives that using a system will help him or her to attain a gain in job performance" (Venkatesh et al., 2003). Previous research by (Chua, Rezaei, Gu, Oh, \& Jambulingam, 2018) on performance expectancy as a determinant variable showed that performance expectancy can influence users' intention to use social networking apps in Malaysia.

\subsection{Social Influence}

Social influence is "the degree to which an individual perceives the importance of others believing he or she should use the new system" (Venkatesh et al., 2003). The entrepreneurs would decide to use social media when spouse, sibling, mentor, influencers, and business competitors make him or her believe the importance of using social media in the business. Even more, there are possibilities that customers' influence could be a reason the entrepreneur uses social media (Pentina, Koh, \& Le, 2012). Consumers and entrepreneurs have different sets of people that can influence them to use social networking apps. Previous research by (Chua et al., 2018) on sets of people that can influence consumers to upload and use social networking apps are friends, family and a colleague. However, for 
an entrepreneur the sets of people that can influence them are broader and include family, sibling, mentor (Venkatesh et al., 2003), customers, competitors (Matikiti, Mpinganjira, \& Roberts-Lombard, 2018) and influencers (Fadhila, 2018).

\subsection{Facilitating Condition}

Facilitating conditions is "the degree to which an individual believes that an organizational and technical infrastructure exists to support use of the system" (Venkatesh et al., 2003). An adequate infrastructure, appropriate skills, and enough resources will influence the entrepreneur and ease the business activities using social media as a marketing tool (Rahman et al., 2020). Previous research by (Tan, 2013) shows that facilitating conditions directly influence the uses of e-learning websites in Taiwan.

\subsection{Propensity to Sharing Information}

The propensity to share information can be one factor that influences entrepreneurs to utilize social media in their industry. Without the tendency to share information, the entrepreneurs will miss out on an opportunity to build their online presence and cannot reach a vast potential customer that readily exists on social media platforms. The more an entrepreneur inclines to post and share it post on social media (comment, product review, upload video, etc.), the more propensity that the entrepreneur will use social media as a marketing tool (Rode, 2016). Previous research by Jarvenpaa and Staples (2000) finds that feelings of sharing information were associated with the actual use of media for information sharing activities among university staff.

\subsection{Viral Marketing Expectancy}

Viral marketing can destroy a business or can push word-of-mouth advertising on social networks and boost product and service sales (Rollins, Anitsal, \& Anitsal, 2014; Hakimey \& Yazdanifard 2014). The use of technology in viral marketing made interaction between entrepreneurs and customers more engaging; thus, this will help spread the viral message to other potential customers (Larson, 2009). Previous research by Isa and Nordin (2018) about viral marketing studied how social media advertising uses viral marketing to promote brands and products. in Malaysia. The researcher studied several popular social media sites in Malaysia and found that viral marketing is positively accepted both by entrepreneurs and consumers. However, viral marketing expectancy variables have never been studied before on its influence towards actual use of social media as a marketing tool.

\subsection{Fear of Pandemic}

Fear of pandemic has altered how people learn, work and live today. Donthu and Gustafsson (2020) stress that with COVID-19 still arising globally, the fear of the 
pandemic will affect how a business does its activities. Moreover, Effendi et al. (2020) suggest using technology and adopting social media as a crucial tool in helping entrepreneurs deal with fear of COVID-19 pandemic to raise for adversity in their business activities. Alqahtani and Rajkhan (2020) in their research about factors that make e-learning success found that lecturers and students' readiness to adopt e-learning is crucial to be successful. However, the fear of pandemic is not yet studied with regards to the actual uses of social media as a marketing tool.

\subsection{Performance Expectancy, Social Influence, Facilitating Condition, Propensity to Sharing Information, Viral Marketing Expectancy, Fear of Pandemic and Social Media Usage}

Centred on the early study on social media adoption and entrepreneurs, the notion is there was inadequate study about Malaysian entrepreneur's social media adoption and use in Malaysia. Previous study results revealed that entrepreneurs in Malaysia are influenced to use internet marketing based on performance expectancy and facilitating conditions (Tan, Chong, \& Lin, 2013). Moreover, Malaysian entrepreneur's familiarity and decision making about social media acceptance is founded on the individual understanding of the business holder, being as a social media user and as an administrator.

Previous research by (Ali, Nair, \& Hussain, 2016) on performance expectancy of students towards usage of computer supported collaborative classrooms showed a positive significant influence on usage. This also is a finding by (Chua et al., 2018) on the behavioural intention as the most influential factor of use behaviour because of greater beta values. However a research done by (Thomas et al., 2017) showed there is no significant influence between performance expectancy and social media usage in the banking sector in Oman.

Therefore, performance expectancy is of direct relevance to the use of social media for a marketing tool by entrepreneurs in Malaysia. This is because entrepreneurs rely on the use of social media to market their product and service. Owing to the feature of being able to market their products and services in limitless locations, social media enables entrepreneurs to use it to reach its customers in a vast market. Thus, if an entrepreneur perceives that the use of social media for digital marketing will contribute meaningfully to enhancing his or her business performance, he or she may be favourably disposed to use it in their marketing activities.

Previous research by Ahmad, Hassan, Mohd Tajuddin, and Wimpi (2018) shows that the university students have high usage of social media with an average of three social media accounts for each student. A research by (Nawi, Mamun, Nasir, \& Muniady, 2019) noted that social influence acts as moderator between facilitating the actual use of social media among students in Malaysia. If the social influence is high the impact of facilitating conditions is also high towards usage of social media. Moreover, social influence variable has a positive 
and significant relationship towards actual use of social media among Turkish entrepreneurs (Turan \& Kara, 2018). For competitors' dimension in social influence, researcher Schillewaert, Ahearne, Frambach, and Moenaert (2005) found that competitors (sales-force from other companies) as a second most important factor that may influence sales persons in their adoption of technology. However, for customer dimension in social influence, researcher Matikiti, Mpinganjira, \& Roberts-Lombard (2018) studied customer pressure as one of the established factors that influence attitude towards the use of social media in South Africa. The finding shows that customers are one of the factors that influence the tourism industry to adopt social media for marketing purposes. Previous research by (Khalid, Jayasainan, \& Hassim, 2018) about influencers that use social networking sites (SNS) found that the influencer can influence social networking sites usage. The study found that the influencer enhances cultural awareness and consumption among youth SNS users in Malaysia.

Previous research by (Serben, 2014) shows that facilitating conditions has a significant relationship with actual use of social media and are moderated by age and gender. The younger the entrepreneurs are, the more they believe using social media will ease their business activities. Also, a male got more support to use social media in their business.

Social media, specifically Facebook and Twitter, is a key platform to build relationships with consumers and for consumers to get information about a brand and its products. Smith (2014) believes that users of social media believe information posted by entrepreneurs and other users in social media are trustworthy and reliable. Hepziba and John (2017) in their research finds out that the goal of social media is to produce content that users will share in social networks known as customer engagement. The opinion of customers on the products, services, and brands can be shared to others via comment and share button.

Previous research by Liu, Shao, Tang, and Fan (2019) studied whether and how factors for social media continuance behaviours work differently between social networking sites and microblogging. In their research, they found that users in social network media found satisfaction in social interaction while sharing information in social media. Research by Nabil Iblasi, Bader, and Ahmad Al-Qreini (2016) study the impact of social media as a marketing tool toward purchasing decisions. In their case study, the researcher posits that social media is an important communication tool that people use to connect to other people or organizations. To this end the finding shows consumers spending a lot of time on social media websites. This is concurring with the idea that social media websites are impactful in influencing consumer purchasing behaviour.

Furthermore, Hepziba and John (2017) suggests that viral marketing involves consumers passing along a company's marketing message to their friends, family, and colleagues with the emotion of surprise often at work, and resembles that of word-of-mouth marketing. Previous research on viral marketing by Zernigah and Sohail (2012) studied consumers' attitude towards viral marketing in Pakis- 
tan. The findings show that consumers attitude towards viral marketing is positive and believe the information in the viral massage will be forwarded to others if the massage deems trustworthy. Hakimey and Yazdanifard (2014) posit that viral marketing can built a company or also can destroys it. The viral massage is so impactful that the good viral massage will strengthen and build company quickly and vice versa.

The fear of COVID-19 has evolved into a health, socioeconomic and humanitarian crises of unprecedented scale and impact in Malaysia (Lim, 2020). Furthermore, due to fear of COVID-19, the conventional face-to-face selling products and services have shifted to online settings. On the economic front, the lockdown is turning into an economic knockout. The economy is nose diving with intensifying negative impacts on jobs, incomes, and livelihoods, disrupting supply chains and upending businesses (Lim, 2020).

\section{Proposed Theoretical Framework}

In this preliminary study, the conceptual model of the relationship of performance expectancy, social influence, facilitating condition, propensity to sharing information, viral marketing expectancy, and fear of pandemic toward social media usage is illustrated in Figure 1.

The proposed theoretical framework in Figure 1 reveals that performance expectancy, social influence, facilitating condition, propensity to sharing information, viral marketing expectancy, and fear of pandemic have an influence towards the social media usage Venkatesh et al. (2003). Researchers suggest that several variables such as propensity to sharing information, viral marketing

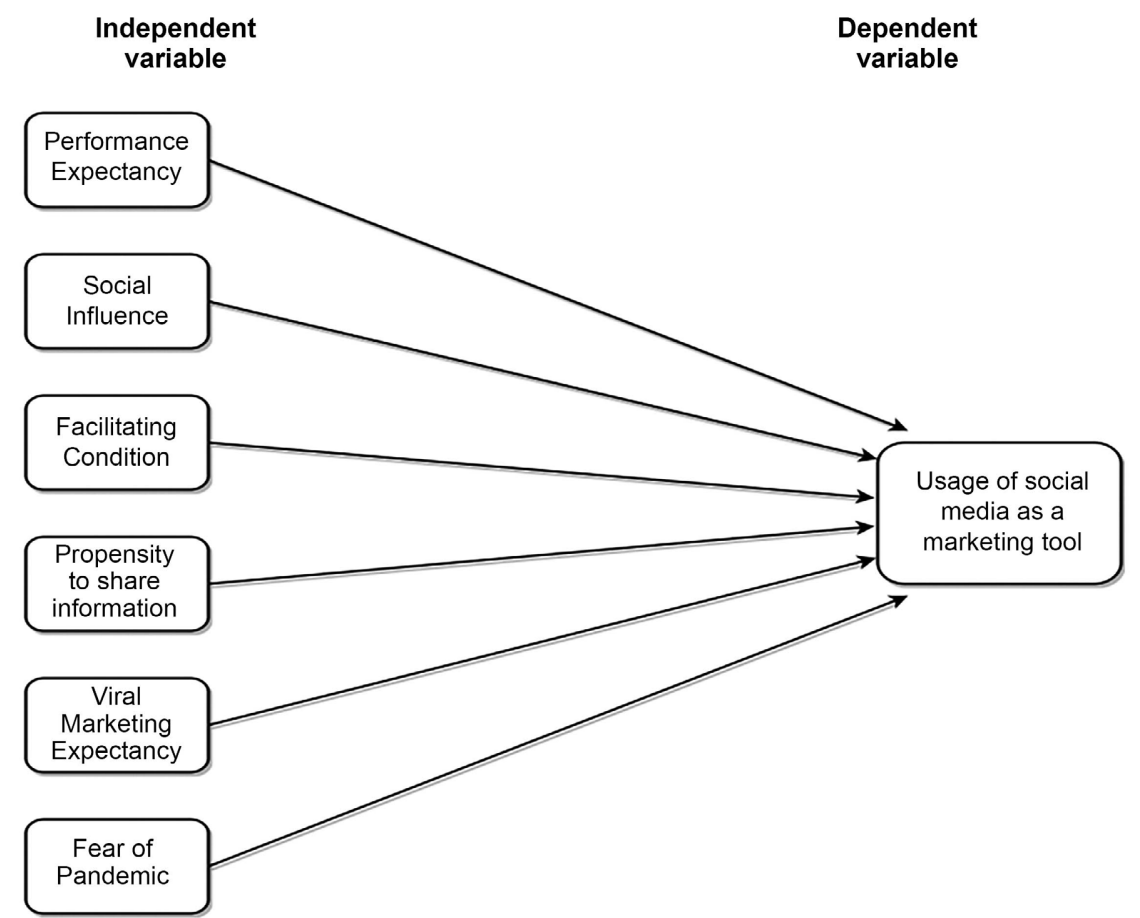

Figure 1. Proposed theoretical framework. Adapted from Venkatesh et al. (2003). 
expectancy, and fear of pandemic are added to measured social media usage. Previously, performance expectancy, social influence, facilitating condition were measured but for variables of propensity to sharing information, viral marketing expectancy, and fear of pandemic there are limited studies done.

\section{Limitation of the Study and Recommendation for Future Research}

This study is limited as there is no mediating or moderating variable included. Future research should include entrepreneurs' intention as mediating variable and gender, age and experience as moderating variable to enhance the findings on the factors that influence social media usage and to improve the possibility of generalization.

\section{Conclusion}

This study attempts to develop a theoretical framework for the relationship between performance expectancy, social influence, facilitating condition, propensity to sharing information, viral marketing expectancy and fear of pandemic towards social media usage as a marketing tool. This study will be conducted among entrepreneurs in Malaysia. Based on the preliminary findings, it can be concluded that studying social media usage as a marketing tool can help entrepreneurs gain competitive edges, build relationship with customers and build business presence in the market.

\section{Conflicts of Interest}

The authors declare no conflicts of interest regarding the publication of this paper.

\section{References}

Ahmad, R., Hassan, N. A., Mohd Tajuddin, J., \& Wimpi, Y. T. (2018). A Study on Social Media Usage among Private University Students in Klang Valley. Jurnal Sultan Alauddin Sulaiman Shah, 5, 257-268. http://journal.kuis.edu.my/jsass/images/vol5bil2/jsass_vol5bil2_020_rahilah.pdf

Ali, F., Nair, P. K., \& Hussain, K. (2016). An Assessment of Students' Acceptance and Usage of Computer Supported Collaborative Classrooms in Hospitality and Tourism Schools. Journal of Hospitality, Leisure, Sport and Tourism Education, 18, 51-60. https://doi.org/10.1016/j.jhlste.2016.03.002

Alqahtani, A. Y., \& Rajkhan, A. A. (2020). E-Learning Critical Success Factors during the COVID-19 Pandemic: A Comprehensive Analysis of E-Learning Managerial Perspectives. Education Sciences, 10, Article No. 216. https://doi.org/10.3390/educsci10090216

Armesh, H., Salarzehi, H., Salarzehi, H., Yaghoobi, N. M., Yaghoobi, N. M., Heydari, A. et al. (2010). Impact of Online/Internet Marketing on Computer Industry in Malaysia in Enhancing Consumer Experience. International Journal of Marketing Studies, 2, 75-86. https://doi.org/10.5539/ijms.v2n2p75

Camilleri, M. A. (2019). Measuring the Hoteliers' Interactive Engagement through Social Media. In P. Liargovas, \& A. Kakouris (Eds.), Proceedings of the European Conference 
on Innovation and Entrepreneurship, ECIE (Vol. 1, pp. 196-204).

Cheng, S., Liu, L., \& Li, K. (2020). Explaining the Factors Influencing the Individuals' Continuance Intention to Seek Information on Weibo during Rainstorm Disasters. International Journal of Environmental Research and Public Health, 17, Article No. 6072. https://doi.org/10.3390/ijerph17176072

Cheng, T. L. (2020). No Recovery from COVID-19 Just yet for Hotel Industry. The Star Online.

Chua, P. Y., Rezaei, S., Gu, M. L., Oh, Y. M., \& Jambulingam, M. (2018). Elucidating Social Networking Apps Decisions: Performance Expectancy, Effort Expectancy and Social Influence. Nankai Business Review International, 9, 118-142. https://doi.org/10.1108/NBRI-01-2017-0003

Dai, R., Feng, H., Hu, J., Jin, Q., Li, H., Wang, R. et al. (2020). The Impact of COVID-19 on Small and Medium-Sized Enterprises: Evidence from Two-Wave Phone Surveys in China. China Economic Review, 67, Article No. 101607. https://doi.org/10.1016/j.chieco.2021.101607

Donthu, N., \& Gustafsson, A. (2020). Effects of COVID-19 on Business and Research. Journal of Business Research, 117, 284-289.

https://doi.org/10.1016/j.jbusres.2020.06.008

Durgam, V. (2015). Social Media and Its Role in Marketing. Business and Economics Journal, 7, 1-5.

Edosomwan, S., Prakasan, S. K., Kouame, D., Watson, J., \& Seymour, T. (2011). The History of Social Media and Its Impact on Business. Management, 16, 79-91.

Effendi, M. I., Sugandini, D., \& Istanto, Y. (2020). Social Media Adoption in SMEs Impacted by COVID-19: The TOE Model. Journal of Asian Finance, Economics and Business, 7, 915-925. https://doi.org/10.13106/jafeb.2020.vol7.no11.915

Eid, R., Abdelmoety, Z., \& Agag, G. (2019). Antecedents and Consequences of Social Media Marketing Use: An Empirical Study of the UK Exporting B2B SMEs. Journal of Business and Industrial Marketing, 35, 284-305.

https://doi.org/10.1108/JBIM-04-2018-0121

Elawadi, I. (2016). Digital Marketing and Social Media: Challenges and Solutions. Journal of Technology, 1-7.

Fadhila, D. (2018). Authenticity and Transparency in Influencer Instagram Content in Indonesia.

http://www.theseus.fi/bitstream/handle/10024/142785/THESIS_FINAL_DRAFT_DIN DA_FADHILA.pdf;jsessionid=443812D1A2D7A47810F2377334E7B238? sequence $=1$

Fortin, D., \& Uncles, M. (2011). The First Decade: Emerging Issues of the Twenty-First Century in Consumer Marketing. Journal of Consumer Marketing, 28, 472-475. https://doi.org/10.1108/07363761111194767

Hakimey, H., \& Yazdanifard, R. (2014). Viral Marketing; Powerful or Weak? The Challenges and Problems Facing Viral Marketing. ResearchGate.

Hassan, S., Shiratuddin, N., \& Abdul Salam, S. (2015). Social Media as Persuasive Technology for Business in Malaysia. International Journal of E-Business Research, 11, 18-39. https://doi.org/10.4018/ijebr.2015040102

Hepziba, R. E., \& John, F. (2017). An Exploratory Study on the Influence of Social Media Marketing Strategies on Customer Engagement. International Journal of Marketing and Human Resource Management (IJMHRM), 8, 1-8.

Isa, N., \& Nordin, N. Z. (2018). Social Media Advertising in Malaysia : The Power of Viral Marketing. International Journal of Business and Management Invention, 7, 74-78. 
Jarvenpaa, S. L., \& Staples, D. S. (2000). The Use of Collaborative Electronic Media for Information Sharing: An Exploratory Study of Determinants. Journal of Strategic Information Systems, 9, 129-154. https://doi.org/10.1016/S0963-8687(00)00042-1

Khalid, N. L., Jayasainan, S. Y., \& Hassim, N. (2018). Social Media Influencers-Shaping Consumption Culture among Malaysian Youth. SHS Web of Conferences, 53, Article No. 02008. https://doi.org/10.1051/shsconf/20185302008

Kumar, A., \& Ayedee, N. (2021). Technology Adoption: A Solution for SMEs to Overcome Problems during COVID-19. Academy of Marketing Studies Journal, 25, 1-16. https://papers.ssrn.com/sol3/papers.cfm?abstract_id=3745814

Larson, R. J. (2009). The Rise of Viral Marketing through the New Media of Social Media. Liberty University.

http://digitalcommons.liberty.edu/cgi/viewcontent.cgi?article=1009\&amp;context=busi fac_pubs

Lim, L. L. (2020). The Socioeconomic Impacts of COVID-19 in Malaysia : Policy Review and Guidance for Protecting the Most Vulnerable and Supporting Enterprises. International Labour Organization.

Lin, J., Li, L., Yan, Y., \& Turel, O. (2018). Understanding Chinese Consumer Engagement in Social Commerce: The Roles of Social Support and Swift Guanxi. Internet Research, 28, 2-22. https://doi.org/10.1108/IntR-11-2016-0349

Liu, Q., Shao, Z., Tang, J., \& Fan, W. (2019). Examining the Influential Factors for Continued Social Media Use: A Comparison of Social Networking and Microblogging. Industrial Management and Data Systems, 119, 1104-1127.

https://doi.org/10.1108/IMDS-05-2018-0221

Liu, Y., \& Bakici, T. (2019). Enterprise Social Media Usage: The Motives and the Moderating Role of Public Social Media Experience. Computers in Human Behavior, 101, 163-172. https://doi.org/10.1016/j.chb.2019.07.029

Malaysian Communication and Multimedia Commission (2018). E-Commerce Consumers Survey 2018.

http://www.mcmc.gov.my

Matikiti, R., Mpinganjira, M., \& Roberts-Lombard, M. (2018). Application of the Technology Acceptance Model and the Technology-Organization-Environment Model to Examine Social Media Marketing Use in the South African Tourism Industry. $S A$ Journal of Information Management, 20, Article No. a90. https://doi.org/10.4102/sajim.v20i1.790

Nabil Iblasi, W., Bader, D. M., \& Ahmad Al-Qreini, S. (2016). The Impact of Social Media as a Marketing Tool on Purchasing Decisions (Case Study on SAMSUNG for Electrical Home Appliances). International Journal of Managerial Studies and Research, 4, 14-28. http://www.arcjournals.org

Nadaraja, R., \& Yazdanifard, R. (2013). Social Media Marketing: Advantages and Disadvantages (pp. 1-10). Researchgate.net.

https://www.researchgate.net/publication/256296291_Social_Media_Marketing_SOCI AL_MEDIA_MARKETING_ADVANTAGES_AND_DISADVANTAGES

Nawi, N. C., Al Mamun, A., Nasir, N. A. M., \& Muniady, R. (2019). Factors Affecting the Adoption of Social Media as a Business Platform: A Study among Student Entrepreneurs in Malaysia. Vision, 23, 1-11. https://doi.org/10.1177/0972262918821200

Pentina, I., Koh, C. A., \& Le, T. T. (2012). Adoption of Social Network Marketing by SMEs. International Journal of Internet Marketing and Advertising, 7, 65-82. https://doi.org/10.1504/IJIMA.2012.044959

Rahman, R. U., Shah, S. M. A., El-Gohary, H., Abbas, M., Khalil, S. H., Al Altheeb, S., \& 
Sultan, F. (2020). Social Media Adoption and Financial Sustainability: Learned Lessons from Developing Countries. Sustainability, 12, Article No. 10616. https://doi.org/10.3390/su122410616

Rode, H. (2016). To Share or Not to Share: The Effects of Extrinsic and Intrinsic Motivations on Knowledge-Sharing in Enterprise Social Media Platforms. Journal of Information Technology, 31, 152-165. https://doi.org/10.1057/jit.2016.8

Rollins, B., Anitsal, I., \& Anitsal, M. M. (2014). Viral Marketing: Techniques and Implementation. Entrepreneurial Executive, 19, 1-17.

Schillewaert, N., Ahearne, M. J., Frambach, R. T., \& Moenaert, R. K. (2005). The Adoption of Information Technology in the Sales Force. Industrial Marketing Management, 34, 323-336. https://doi.org/10.1016/j.indmarman.2004.09.013

Serben, D. F. (2014). The Examination of Factors Influencing Social Media Usage by African American Small Business Owners Using UTAUT Model. ProQuest LLC.

Smith, T. (2014). Consumer Perceptions of a Brand's Social Media Marketing. Master's Thesis, University of Tennessee. https://trace.tennessee.edu/utk_gradthes/3184/

Tan, K. S., Chong, S. C., \& Lin, B. (2013). Intention to Use Internet Marketing: A Comparative Study between Malaysians and South Koreans. Kybernetes, 42, 888-905. https://doi.org/10.1108/K-12-2012-0122

Tan, P. J. B. (2013). Applying the UTAUT to Understand Factors Affecting the Use of English E-Learning Websites in Taiwan. SAGE Open, 3. https://doi.org/10.1177/2158244013503837

Teresa, M., \& Ceyrat, T. (2017). Use of Social Media: Empirical Comparison between Europe and Middle East. NOVA Information Managemant School (NIMS). https://run.unl.pt/handle/10362/20653

Thomas, T. R., Singh, P. K., \& Aulia, S. (2017). Acceptance and Use of Social Media Banking in Sultanate of Oman. International Journal of Managerial Studies and Research, 5, 90-96. https://doi.org/10.20431/2349-0349.0511010

Turan, M., \& Kara, A. (2018). Online Social Media Usage Behavior of Entrepreneurs in an Emerging Market: Reasons, Expected Benefits and Intentions. Journal of Research in Marketing and Entrepreneurship, 20, 273-291. https://doi.org/10.1108/JRME-09-2016-0034

Turner, J., \& Akinremi, T. (2020). The business Effects of Pandemics-A Rapid Literature Review (Vol. 1). Enterprise Research Centre. http://www.enterpriseresearch.ac.uk/

Vedenhaupt, L. L. (2016). Analyzing the Relationship between Social Media Usage and Ticket Sales at Small Nonprofit Performing Arts Organizations. Capella University.

Venkatesh, V., Michael, G. M., Gordon, B. D., \& Fred, D. D. (2003). User Accaptance of Information Technology: Toward a Unified View. MIS Quarterly, 27, 425-478. https://doi.org/10.2307/30036540

Zernigah, K. I., \& Sohail, K. (2012). Consumers' Attitude towards Viral Marketing in Pakistan. Management \& Marketing, 7, 645-662. 